\title{
Impact of COVID-19 and Mitigation Plans on Essential Health Services: Institutional Experience of St. Paul's Hospital Millennium Medical College
}

Firaol Dandena ( $\square$ firadandena123@gmail.com )

St. Paul's Hospital Millennium Medical College

Berhanetsehay Teklewold

St. Paul's Hospital Millennium Medical College

Dagmawi Anteneh

St. Paul's Hospital Millennium Medical College

\section{Research Article}

Keywords: Essential Health Services, Triple Setup, COVID-19, SPHMMC, Ethiopia

Posted Date: June 28th, 2021

DOI: https://doi.org/10.21203/rs.3.rs-604989/v1

License: (c) (i) This work is licensed under a Creative Commons Attribution 4.0 International License.

Read Full License 


\section{Abstract}

\section{Background}

Health systems around the world are being challenged by on-going COVID-19 pandemic . The COVID-19 pandemic and associated response can have a significant downstream effect on access to routine health care services, and indirectly cause morbidity and mortality from causes other than the disease itself ,especially in resource-poor countries such Ethiopia. This study aimed to explore the impact of the pandemic on these service and measures taken to combat the effect.

\section{Methods}

The study was conducted at St. Paul's hospital millennium medical college (SPHMMC). The study was conducted from December 15, 2020 to January 15, 2021 using comparative cross- sectional study design. We collected data on the number of clients getting different essential healthcare services from May to October 2019 (Pre COVID) and same period in 2020 (during COVID-19 pandemic) from patient registry book. The analysis was done with SPSS version 24 software.

\section{Result}

Overall, the essential services of SPHMMC were affected by COVID-19 pandemic. The most affected service is inpatient admission that showed $73 \%$ (2044 to 682) reduction from pre- COVID period and the least affected is maternal service, which only decrease by $13 \%$ (3671 to 3177). During the 6 months after COVID-19 pandemic, there is a progressive increment in number of clients getting essential health services.

Conclusion

The establishment of a triple setup for fighting against COVID-19, which encompass; non COVID service, isolation centre and COVID-19 treatment centre played a vital role in preserving essential health services.

\section{Introduction}

The outbreak of pneumonia of an unknown ethology was reported in December 2019 in Wuhan, Hubei Province, China (1). Following this, a novel coronavirus, SARS-CoV-2, was identified as the causative virus for the pandemic in China and other parts of the world by the World Health Organization (WHO) (2).

Then the emergence of the new coronavirus (2019-nCoV) was announced by World Health Organization (WHO) as a public health emergency of international concern (PHEIC) on January 30, 2020 (2).

As of March 25, 2021, more than 235 countries/territories are affected with more than 120,383,289 cases and 2, 666, 91 deaths were recorded worldwide. In Africa, 57 countries/territories are affected with more than 4,124,997 COVID-19 cases and more than 109,586 deaths were reported across the continent. On 
March 13, COVID-19 positive case was first reported in Ethiopia. As of March 25, 2021, a total of 187,365 confirmed COVID-19 cases and 2,657 deaths were recorded in the country (3).

The supply and demand for health care services have been shown to affect access to these services in the past. Patients may be hesitant to seek treatment because they believe health facilities are infected, or they have doubts about the competence of health care providers to implement adequate infection prevention and control procedures. When health systems are overburdened by outbreaks, people may be unable to get the care they need, resulting in an increase in the number of deaths from COVID-19-related and non-COVID-19 causes. $(4,5$, and 6$)$.

Many countries are struggling to strike a balance between COVID 19-related initiatives and the necessity to continue providing other critical health services. Many routine and optional services have been halted, and new techniques are being developed in response to the changing pandemic situation. (7).

A country's ability to maintain the supply of basic health care is determined by a number of factors. These are baseline health system capacity, illness burden, and COVID-19 transmission locally. (8).

The Ethiopian essential health service package includes reproductive, maternal, neonatal, child, and adolescent health services; major communicable diseases; non-communicable diseases; surgical care; and emergency and critical care (12).

The Ebola outbreak in 2014-2015 resulted in an 18\% drop in average health-care utilization. The decline was even greater for maternity and child health services, such as facility-based deliveries, which fell by $28 \%$. The number of mortality from measles, malaria, HIV/AIDS, and tuberculosis has increased. Which was attributable to health system failures to provide those services $(9,10$, and 11).

Studies done in 22 hospitals of France (a country that has been struck early and with a high intensity of the COVID-19 wave) showed $26 \%$ decline of all emergency department visits, including a decrease of $34 \%$ of strokes, $32 \%$ of transitory ischemic attacks, $64 \%$ of unstable angina, $42 \%$ of appendicitis and $36 \%$ of seizures $(13,14)$.

Global financing faculty predicted in Ethiopia that 1,229,200 children have the potential to leave without oral antibiotics for pneumonia, 3,164,600 children without DPT vaccinations, 238,000 women without access to facility-based deliveries, and fewer than 2,243,700 women receiving family planning services. As a result of compromise in all essential services, child mortality in Ethiopia could increase by 15 percent and maternal mortality by 8 percent over the next year (15).

A study done in Switzerland showed $43 \%$ decrease of elective visceral surgical procedures was observed after Covid-19 (295 vs. 165, p < 0.01), while the emergency operations (all specialties) decreased by $39 \%$ (1476 vs. 897, $p<0.01$ ). Fifty-two and 38 major oncological surgeries were performed, respectively, representing a $27 \%$ decrease $(p=0.316)$. Outpatient consultations dropped by $59 \%$, from 728 to $296(p<$ 0.01) (16). 


\section{Methods}

\section{Study setting}

The study was conducted at St. Paul's Hospital Millennium Medical College which is the second largest hospital in Ethiopia located in Addis Ababa. It has different departments with speciality and subspeciality services like surgery, obstetrics and gynaecology, paediatrics and child health, internal medicine, and other clinics. The hospital is staffed with more than 3,000 healthcare and administrative workers. Annually, more than 1,000,000 patients are seen in the hospital (16).

\section{Study period}

The study was conducted from December 15, 2020 to January 15, 2021

\section{Study design}

Comparative cross- sectional study

\section{Data collection and procedure}

We collected data on the number of clients attending different essential healthcare services from patient registry books in different service areas of the hospital from May 1st to October 31, 2019 and from May 1 st to October 31, 2020. Aggregate data that were collected during the emergence of COVID-19 pandemic was compared with the number of visits of the same six months of previous year (pre- COVID). Data collectors also asked interview questions and observe service areas of the hospital.

\section{Data analysis}

Data was coded, entered and cleaned using SPSS version 24 software package by principal investigator. Simple descriptive statistics such as frequencies distribution was done as appropriate and the result was presented in tables and graphs.

\section{Results}

This study assessed the effect of COVID-19 pandemic on six essential services provided at St. Paul's hospital millennium medical college( SPHMMC) by taking average of six months of (COVID) season with (pre- COVID)season. Outpatient visits decreased by $57 \%$ from pre-covid time $(37,739$ to 16,121$)$ ( $P<$ 0.0126) (Table 3).The average number of patient visiting Medical, surgical, paediatrics and psychiatry average outpatient visits showed more than a half decrement from similar period in the previous year; from 13,888 to 6,489 (53.27\%), 6,431 to 3,000 (53.35\%), 2,112 to $1,006(52.37 \%)$ and 1,460 to 647 (55.68\%) respectively. Dermatology and ophthalmology outpatient visits showed $75 \%$ decrement $(1,268$ to 289 and 1,351 to 324 respectively) from pre-COVID period. There was no significant change in number of patients visiting renal transplant, palliative and oncology outpatient departments (Table 1\&2). 
The average number of patients visiting the emergency departments decline by $47 \%$ (4190 to 2204$)(\mathrm{P}<$ 0.0420) during the COVID season (Table 3). Paediatrics emergency and adult emergency showed $70 \%$ reduction in patients visits from pre COVID period, (554 to 164) and (1,526 to 485) respectively. The number of patients visiting our trauma wing; Addis Ababa Burn, Emergency and Trauma Hospital (AaBET Hospital) showed decrement by $45 \%$ ( 966 to 527 ) patients per month on average) (Table 1\&2).

Family planning services decreased by $47 \%$ (from 440 to 233 ) whereas dialysis service decreased by $53 \%$ ( 144 to 68 ) during COVID season as compared to similar six months period prior to the emergence of COVID-19 pandemic.

Maternal services are the least affected as compared to other essential health services, only decreased by $13 \%(3,671$ to 3,167$)$. The average number of mothers came for antenatal visit decreased by $15 \%(2,084$ to 1,746$)$ and post-natal visits showed $16 \%$ reduction. Regarding facility delivery service; spontaneous vaginal delivery decreased by $9 \%$ ( 505 to 462 ) and instrumental delivery decreased by one third (60 to $37)$, while the number of caesarean section done during COVID-19 pandemic showed slight increment (Table 1\&2).

The average number of emergency surgeries done during COVID-19 pandemic showed $24 \%$ reduction (254 to 193), whereas the average number of elective surgeries done decreased by $56.3 \%$ (384 to 168) as compared from similar six months period in the pre-COVID year. The most affected service by COVID-19 pandemic is inpatient admission that showed $73 \%$ (2,044 to 682) reduction from similar six months period prior to SARS-CoV-2 emergence and prominent effect on surgical admission decreasing by $64 \%$ (355 to 128) (Table 1 \&2). 
Table 1

Number of visits to essential healthcare-delivering units in SPHMMC (from May 1to October 31, 2019)

\begin{tabular}{|c|c|c|c|c|c|c|c|}
\hline $\begin{array}{l}\text { Essential healthcare } \\
\text { type }\end{array}$ & $\begin{array}{l}\text { May } \\
2019\end{array}$ & $\begin{array}{l}\text { June } \\
2019\end{array}$ & $\begin{array}{l}\text { July } \\
2019\end{array}$ & $\begin{array}{l}\text { August } \\
2019\end{array}$ & $\begin{array}{l}\text { September } \\
2019\end{array}$ & $\begin{array}{l}\text { October } \\
2019\end{array}$ & $\begin{array}{l}\text { Monthly } \\
\text { average }\end{array}$ \\
\hline Outpatient services & 12,413 & 15627 & 13913 & 15775 & 12008 & 13596 & 13888 \\
\hline Internal Medicine & 5605 & 6650 & 5780 & 6805 & 7925 & 5821 & 6431 \\
\hline Surgery & 3400 & 3765 & 3199 & 3412 & 3156 & 2808 & 3620 \\
\hline Gynaecology & 1027 & 1217 & 1180 & 1104 & 1648 & 1432 & 1268 \\
\hline Dermatology & 888 & 930 & 1890 & 1756 & 1596 & 1049 & 1351 \\
\hline Dental \& Maxillofacial & 7102 & 3651 & 3110 & 4438 & 4606 & 4713 & 4603 \\
\hline 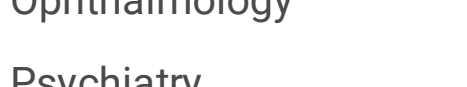 & 1450 & 1289 & 1181 & 1510 & 1696 & 1637 & 1460 \\
\hline Ear Nose \& Throat & 1330 & 1596 & 1867 & 1814 & 1706 & 1598 & 1651 \\
\hline (ENT) & 242 & 216 & 240 & 223 & 853 & 195 & 328 \\
\hline Renal Transplant & 6 & 5 & 6 & 5 & 4 & 4 & 5 \\
\hline Palliative care & 1182 & 1071 & 915 & 1007 & 1038 & 920 & 1022 \\
\hline Oncology & 1749 & 2059 & 2235 & 2055 & 2188 & 2389 & 2112 \\
\hline \multicolumn{8}{|l|}{ Paediatrics } \\
\hline Emergency services & 503 & 610 & 499 & 579 & 549 & 554 & 554 \\
\hline Paediatric Emergency & 1330 & 1255 & 1217 & 1348 & 2815 & 1193 & 1526 \\
\hline Adult Emergency & 929 & 1346 & 997 & 979 & 1462 & 1156 & 1144 \\
\hline $\begin{array}{l}\text { Gynaecology } \\
\text { Emergency }\end{array}$ & 948 & 1018 & 954 & 997 & 1223 & 658 & 966 \\
\hline \multicolumn{8}{|l|}{ AaBET Emergency } \\
\hline Other services & 276 & 541 & 426 & 416 & 551 & 435 & 440 \\
\hline Family planning & 14 & 14 & 22 & 12 & 17 & 16 & 16 \\
\hline Cervical cancer & 49 & 69 & 79 & 82 & 69 & 47 & 67 \\
\hline Voluntary Counselling \& & 5 & 15 & 10 & 10 & 15 & 4 & 10 \\
\hline Testing & 95 & 95 & 93 & 92 & 413 & 81 & 144 \\
\hline \multicolumn{8}{|l|}{$\begin{array}{l}\text { Post Exposure } \\
\text { Prophylaxis }\end{array}$} \\
\hline Dialysis & & & & & & & \\
\hline
\end{tabular}




\begin{tabular}{|llllllll|}
\hline $\begin{array}{l}\text { Essential healthcare } \\
\text { type }\end{array}$ & $\begin{array}{l}\text { May } \\
\mathbf{2 0 1 9}\end{array}$ & $\begin{array}{l}\text { June } \\
\mathbf{2 0 1 9}\end{array}$ & $\begin{array}{l}\text { July } \\
\mathbf{2 0 1 9}\end{array}$ & $\begin{array}{l}\text { August } \\
\mathbf{2 0 1 9}\end{array}$ & $\begin{array}{l}\text { September } \\
\mathbf{2 0 1 9}\end{array}$ & $\begin{array}{l}\text { October } \\
\text { 2019 }\end{array}$ & $\begin{array}{l}\text { Monthly } \\
\text { average }\end{array}$ \\
\hline Maternal Service & 495 & 530 & 502 & 474 & 532 & 499 & 505 \\
$\begin{array}{l}\text { Spontaneous Vaginal } \\
\text { Delivery }\end{array}$ & 41 & 70 & 65 & 54 & 73 & 59 & 60 \\
Instrumental delivery & 303 & 370 & 384 & 368 & 394 & 393 & 368 \\
Caesarean section & 1 & 1 & 0 & 0 & 0 & 0 & - \\
Maternal death & 739 & 1124 & 2531 & 2592 & 2868 & 2652 & 2084 \\
Antenatal care & 503 & 516 & 552 & 668 & 880 & 702 & 636 \\
Postnatal care & & & & & & & \\
\hline Surgical Service & 138 & 329 & 248 & 253 & 273 & 286 & 254 \\
Emergency surgery & 243 & 446 & 399 & 393 & 405 & 423 & 384 \\
Elective surgery & & & & & & & \\
\hline Inpatient Service & 330 & 370 & 366 & 336 & 378 & 349 & 355 \\
Surgical ward & 83 & 91 & 89 & 92 & 94 & 55 & 84 \\
Medical ward & 55 & 82 & 73 & 67 & 68 & 65 & 68 \\
Paediatrics ward & 452 & 464 & 523 & 515 & 571 & 456 & 497 \\
Maternity ward & 108 & 141 & 161 & 131 & 175 & 209 & 154 \\
Gynaecology ward & 662 & 891 & 889 & 833 & 1183 & 862 & 886 \\
Others & 1690 & 2039 & 2101 & 1974 & 2469 & 1996 & 2044 \\
$\begin{array}{l}\text { Total inpatient } \\
\text { admission }\end{array}$ & & & & & & & \\
\hline
\end{tabular}

*Others: Dental \& Maxillofacial, Ophthalmology, Psychiatry, ENT, ICU and Renal Transplant 
Table 2

Number of visits to essential healthcare-delivering units in SPHMMC (from May 1to October 31, 2020)

\begin{tabular}{|c|c|c|c|c|c|c|c|}
\hline $\begin{array}{l}\text { Essential healthcare } \\
\text { type }\end{array}$ & $\begin{array}{l}\text { May } \\
2020\end{array}$ & $\begin{array}{l}\text { June } \\
2020\end{array}$ & $\begin{array}{l}\text { July } \\
2020\end{array}$ & $\begin{array}{l}\text { August } \\
2020\end{array}$ & $\begin{array}{l}\text { September } \\
2020\end{array}$ & $\begin{array}{l}\text { October } \\
2020\end{array}$ & $\begin{array}{l}\text { Monthly } \\
\text { average }\end{array}$ \\
\hline Outpatient services & 3,297 & 6,172 & 6,497 & 7,010 & 8,141 & 7,820 & 6,489 \\
\hline Internal Medicine & 2,551 & 2,255 & 2,254 & 3,235 & 3,725 & 3,976 & 3,000 \\
\hline Surgery & 769 & 866 & 890 & 1,128 & 1,502 & 1,477 & 1,105 \\
\hline Gynaecology & 0 & 58 & 186 & 326 & 475 & 686 & 289 \\
\hline Dermatology & 252 & 169 & 184 & 242 & 388 & 711 & 324 \\
\hline Dental \& Maxillofacial & 232 & 494 & 928 & 1,696 & 2,495 & 3,572 & 1,569 \\
\hline 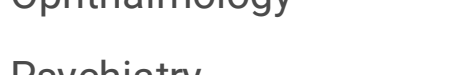 & 602 & 598 & 615 & 697 & 594 & 777 & 647 \\
\hline Far Nare \& Throt (ENT) & 0 & 234 & 510 & 629 & 879 & 1,078 & 555 \\
\hline Eal ivose $\alpha$ litud (EIVI) & 170 & 270 & 267 & 259 & 333 & 350 & 275 \\
\hline Renal Iransplant & 1 & 0 & 2 & 3 & 4 & 4 & 3 \\
\hline Pamative care & 538 & 804 & 832 & 1,016 & 1,075 & 987 & 879 \\
\hline Paediatrics & 473 & 418 & 917 & 690 & 2,168 & 1,373 & 1,006 \\
\hline Emergency services & 173 & 116 & 172 & 187 & 254 & 205 & 164 \\
\hline Paediatric Emergency & 426 & 400 & 554 & 571 & 701 & 694 & 485 \\
\hline Adult Emergency & 1063 & 1002 & 879 & 1,004 & 1135 & 1064 & 1028 \\
\hline $\begin{array}{l}\text { Gynaecology } \\
\text { Emergency }\end{array}$ & 629 & 538 & 260 & 372 & 595 & 431 & 527 \\
\hline \multicolumn{8}{|l|}{ AaBET Emergency } \\
\hline Other services & 220 & 178 & 298 & 230 & 286 & 265 & 223 \\
\hline Family planning & 1 & 0 & - & - & 17 & 16 & 6 \\
\hline Cervical cancer & 0 & 0 & 6 & 77 & 4 & 0 & 14 \\
\hline Voluntary Counselling \& & 0 & 1 & - & 194 & 15 & 0 & 3 \\
\hline Testing & - & - & 206 & & 211 & 200 & 68 \\
\hline \multicolumn{8}{|l|}{$\begin{array}{l}\text { Post Exposure } \\
\text { Prophylaxis }\end{array}$} \\
\hline Dialysis & & & & & & & \\
\hline
\end{tabular}

*Others: Dental \& Maxillofacial, Ophthalmology, Psychiatry, ENT, ICU and Renal Transplant 


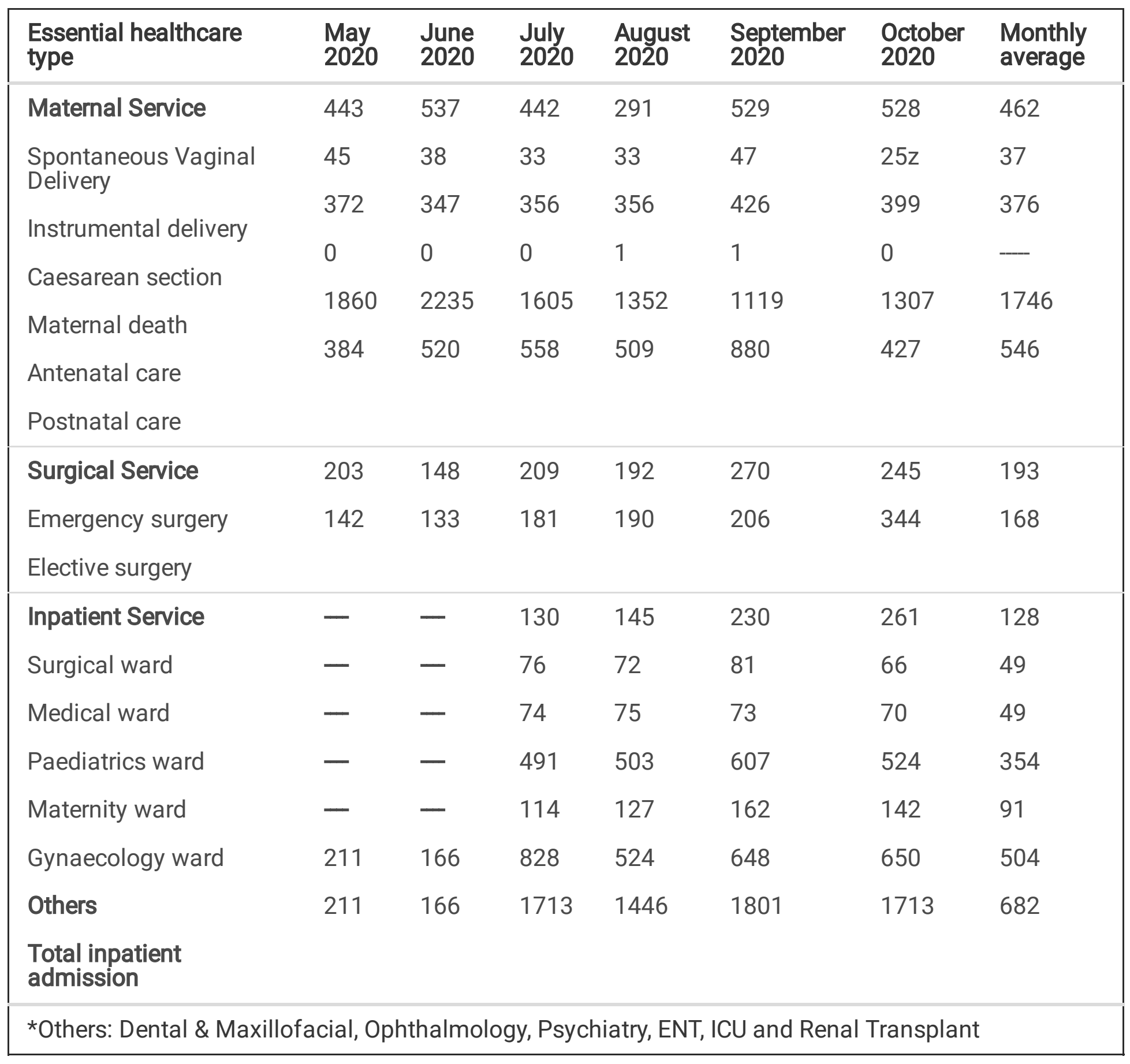


Table 3

chi -square test between per- COVID-19 and COVID-19 group

\begin{tabular}{|c|c|c|c|}
\hline Essential healthcare type & $\begin{array}{l}\text { per- COVID-19 } \\
\text { season(average) }\end{array}$ & $\begin{array}{l}\text { COVID-19 } \\
\text { season } \\
\text { (average) }\end{array}$ & $P$ value \\
\hline Out patient & 13888 & 6,489 & \multirow{12}{*}{$\begin{array}{l}0.0126 \\
a\end{array}$} \\
\hline Internal Medicine & 6431 & 3,000 & \\
\hline Surgery & 3620 & 1,105 & \\
\hline Gynaecology & 1268 & 289 & \\
\hline Dermatology & 1351 & 324 & \\
\hline \multirow{2}{*}{$\begin{array}{l}\text { Dental \& Maxillofacial } \\
\text { Ophthalmology }\end{array}$} & 4603 & 1,569 & \\
\hline & 1460 & 647 & \\
\hline \multirow{2}{*}{$\begin{array}{l}\text { Psychiatry } \\
\text { Ear Nose \& Throat (ENT) }\end{array}$} & 1651 & 555 & \\
\hline & 328 & 275 & \\
\hline Renal Transplant & 5 & 3 & \\
\hline Palliative care & 1022 & 879 & \\
\hline Oncology & \multicolumn{2}{|c|}{ Paediatrics } & \\
\hline Emergency & 554 & 164 & \multirow{5}{*}{$\begin{array}{l}0.0420 \\
\mathrm{a}\end{array}$} \\
\hline Paediatric Emergency & 1526 & 485 & \\
\hline Adult Emergency & 1144 & 1028 & \\
\hline Gynaecology Emergency & 966 & 527 & \\
\hline \multicolumn{3}{|l|}{ AaBET Emergency } & \\
\hline Other services & 440 & 223 & \multirow{6}{*}{$\begin{array}{l}0.0657 \\
a\end{array}$} \\
\hline Family planning & 16 & 6 & \\
\hline Cervical cancer screening & 67 & 14 & \\
\hline Voluntary Counselling \& Testing & 10 & 3 & \\
\hline Post Exposure Prophylaxis & 144 & 68 & \\
\hline Dialysis & & & \\
\hline
\end{tabular}




\begin{tabular}{|c|c|c|c|}
\hline Essential healthcare type & $\begin{array}{l}\text { per- COVID-19 } \\
\text { season(average) }\end{array}$ & $\begin{array}{l}\text { CoVID-19 } \\
\text { season } \\
\text { (average) }\end{array}$ & $P$ value \\
\hline Maternal Service & 505 & 462 & \multirow{7}{*}{$\begin{array}{l}0.0947 \\
\mathrm{a}\end{array}$} \\
\hline Spontaneous Vaginal Delivery & 60 & 37 & \\
\hline Instrumental delivery & 368 & 376 & \\
\hline Caesarean section & 0 & 0 & \\
\hline Maternal death & 2084 & 1746 & \\
\hline Antenatal care & 636 & 546 & \\
\hline \multicolumn{3}{|l|}{ Postnatal care } & \\
\hline Surgical Service & 254 & 193 & \multirow{3}{*}{$\begin{array}{l}0.1623 \\
\mathrm{a}\end{array}$} \\
\hline Emergency surgery & 384 & 168 & \\
\hline \multicolumn{3}{|l|}{ Elective surgery } & \\
\hline Inpatient Service & 355 & 128 & \multirow{8}{*}{$\begin{array}{l}0.0638 \\
\mathrm{a}\end{array}$} \\
\hline Surgical ward & 84 & 49 & \\
\hline Medical ward & 68 & 49 & \\
\hline Paediatrics ward & 497 & 354 & \\
\hline Maternity ward & 154 & 91 & \\
\hline Gynaecology ward & 886 & 504 & \\
\hline Others & 2044 & 682 & \\
\hline Total & & & \\
\hline
\end{tabular}

${ }^{a}$ group $p$ value

Regarding the number of patients visiting SPHMMC during the consecutive six months after the emergence of COVID-19 in Ethiopia, there is an overall increment. The number of patients visiting outpatient departments increased by $61 \%$ (8885 to 22,811), whereas visits in different emergency departments increased by $5 \%$ (2291 to 2394 ) over a period of six months. The number of surgeries (both elective \& emergency) done increased by $41 \%$ (345 to 589 ), whereas inpatient admissions by $88 \%$ ( 211 to 1,713). Unlike the overall increment, maternal services are decreased by $13 \%(3,104$ to 2,686$)$ (Fig. $1 \& 2)$.

\section{Discussion}


Overall, the essential services of SPHMMC were affected by the COVID-19 pandemic. In contrary to Ethiopian Federal Ministry of Health (FMOH) prediction, better number of clients were served in maternal and emergency services. This could be attributed to the absence of restriction on maternal and emergency services unlike other non-emergent services that were fully or partially closed in the early phase of the pandemic to reduce transmission of COVID-19. Continuous awareness creation done by the hospital about COVID-19 on the symptoms, prevention measures and what to do if clients have symptoms or doubts using different social media platforms, mainstream medias like television channels, and delivering information via a free call centre. The Hospital also establish a triple setup for fighting against COVID-19, which encompass; non COVID service, isolation centre for suspect patients and COVID19 treatment centre for confirmed patients with its own staff and separate restricted space. In addition to the triple setup, different teams( sampling team, ambulance team, PPE quantification team, IPC team, safety \& quality team specific to COVID-19 isolation and treatment centre)were organized so as to ease and facilitate early testing \& notification of result for suspect patients, contact tracing, patient transfer, rational use \& supply of Personal Protective Equipment (PPE), availing standard and transmission based precaution facilities, to safeguard if proper IPC measures were taken \& sustained as well as if the services delivered are of with the expected quality. On top of the above measures, task force unit composed of hospital managers and key personnel's that involve in leading different service areas \& units which affect COVID-19 service directly or indirectly was established. This taskforce is responsible for managing challenges, putting decisions on important issues and plotting plans on the way forward based on scientific evidences.

When we see the result of this research as comparable to other similar studies: Studies done in 22 hospitals of France showed a decrease in all emergency department visits by $26 \%(12,13)$. This study showed a much higher decrement in the percentage of patients visiting all emergency departments of the hospital, which is $47 \%$ as compared with pre-COVID era. There is significant association between decrease in the number of patient visiting emergency department with COVID 19 occurrence $(P>0.0420)$ (Table 3).

In a study done in Ireland paediatric emergency department, the attendance for the three-month period from March to May 2020 (COVID period) was 21,545, a drop of $46 \%$ was seen from 39,772 on the same period in 2018/2019 (17). Much higher result is seen in this study in paediatrics emergency department, the attendance decreased during COVID period by $70 \%$ (from 554 to 164 patients per month).

According to our finding, maternal services decreased by $13 \%(3,671$ to 3,177$)$, which is comparable to prediction done by Population Foundation of India (PFI), a decline of $10 \%$ in coverage of pregnancyrelated services (18). But this finding has better maternal service attendance as compared to the findings observed during Ebola outbreak in 2014 and 2015, where facility-based deliveries dropped by $28 \%$ (9).

Global financing faculty predicted maternal mortality will increase by 8 percent in 2020 after the emergence of COVID-19 pandemic (14) but our study showed that there was no increment in maternal mortality as compared with similar period prior to the emergence of the pandemic. 
A study done in Switzerland showed 39\% decrement in urgent operations (all specialties 1476 vs. 897, p< $0.01)$ (15). Better finding is observed in our study, $24 \%$ reduction in the number of emergency surgeries done during COVID-19 pandemic, this could result from having separate isolation surgical room and performing operations for emergency cases irrespective of patient's COVID-19 result while maintaining the necessary Infection Prevention \& Control (IPC) measures is undeniable. Regarding elective visceral surgeries, the study in Switzerland showed a 43\% reduction after the emergence of COVID-19 (295 vs 165, $\mathrm{p}<0.01$ ) (15). A bit higher result was found in this study, which showed a $56.3 \%$ (384 to 168) reduction in elective surgeries during COVID-19 pandemic, this could be attributed to the fact that elective surgeries are performed after RT-PCR test for COVID-19 is negative and the result arrived within 72 hrs of the surgery, the result usually takes $48-96 \mathrm{hrs}$. Outpatient surgical consultations dropped by $59 \%$, from 728 to 296 ( $p$ < 0.01) in Switzerland study (15). Similar result was observed in this study, the number of patients visiting surgical OPD decreased by $53.35 \%(6,431$ to 3,000$)$ as compared between before and after the emergence of COVID-19.

When we compare the number of patients getting essential services during six months after the emergence of COVID-19, it showed progressive increment in all services except maternal services which drop by $13 \%$ (3104 to 2686 ). This can be due to a surge of clients from other private and public healthcare facilities and hospitals as well as home at the initial phase of the pandemic because of full or partial closure of most of the facilities as a result of fear, stigma, and misinformation.

This study showed significant association between the occurrence of COVID 19 and number of client decrease seen in outpatient $(p<0.0126)$ and emergency departments $(p<0.0420)($ Table 3$)$. This may be due to extended appointment for chronic patients and restriction in number of patient seen in outpatient clinics, wereas in emergency department could be the fear of contracting COVID 19 while visiting for other concern.

\section{Conclusion And Recommendation}

The number of client visit in almost all essential healthcare services declined during COVID-19 pandemic. The most affected services were inpatient admission that showed $73 \%(2,044$ to 682$)$ reduction from previous year and the list affected is maternal services only decreased by $13 \%(3,671$ to 3,177$)$. During six months follow up after the emergence of COVID-19, progressive increment in number of patients getting essential services was observed.

Essential healthcare services are as important as COVID-19 prevention and treatment. These services should be provided alongside with COVID-19 services. We can improve the number of clients visiting hospitals in times of such pandemic by endorsing continuous information campaign with available media, implementation and monitoring of IPC measures, and establishing holistic triple setup for delivering quality medical service in times of such pandemic.

A further degree of the health care system's rearrangement at the country level should be the classification of "COVID" and "non-COVID" health facilities in each town in the event of a particularly 
significant caseload. On the one hand, this helps us to limit the danger of contamination, enhance patient routes, and combine health facilities and skilled caregivers; while on the other hand, it allows us to continue managing non-COVID patients without raising risk.

In terms of hospital setup, we advocate establishing a triple setup to combat COVID-19, which includes non-COVID services, an isolation center for suspect patients, and a COVID-19 treatment center with its own staff and restricted space.

\section{Limitation}

We did not include all essential services and it was conducted in a single hospital.

\section{Abbreviations}

COVID-19

Coronavirus disease

$\mathrm{FMOH}$

Federal Ministry of Health

SPHMMC

St. Paul's Hospital Millennium Medical College

SPSS

Statistical Package for Social Sciences

PPE

Personal protection equipment

WHO

World Health Organization

\section{Declarations}

\section{Acknowledgment}

We would like to thank our management team for their willingness to be involved in this study and invaluable insights, shared at such a challenging time.

\section{Authors' contributions}

BT conceived of and designed the research, reviewed the literature, prepared the data and contributed to the revision of the final manuscript. FD drafted the manuscript, discussed the results, performed the analysis and contributed to the revision of the final manuscript. DA supported data preparation, conducted data collection and analysis, and contributed to the revision of the final manuscript. All authors read and approved the final manuscript. 


\section{Funding}

Not applicable. No funding was received for this work.

\section{Availability of data and materials}

The datasets used and/or analysed during the current study are available from the corresponding author upon reasonable request.

\section{Competing interests}

The authors declare that they have no competing interests.

\section{Ethics approval and consent to participate}

The current manuscript had ethical approval from Saint Paul's Hospital Millennium Medical College (SPHMMC) IRB as of the original research proposal which entitled "Impact of Covid-19 and Mitigation Plans on Essential Health Services: Institutional Experience of St. Paul's Hospital Millennium Medical College" .Informed consent was obtained from all study participants before they enrolled in to the study. They were told that their participation is voluntary, could withdraw any time or refuse to answer to any question if they want to. No information concerning the individual was passed to a third party. Therefore, in general we carried out the current research by fulfilling all the requirements of the institutional (SPHMMC) IRB guidelines and relevant guidelines of BMC.

\section{Consent for publication}

Not applicable

\section{References}

1. Chen N, Zhou M, Dong X, Qu J, Gong F, Han Y, et al. Epidemiological and clinical characteristics of 99 cases of 2019 novel coronavirus pneumonia in Wuhan, China: a descriptive study. The Lancet. 2020 Feb 15;395(10223):507-13.

2. IHR Emergency Committee on Novel Coronavirus (2019-nCoV) [Internet]. [cited 2020 Nov 12]. Available from: https://www.who.int/director-general/speeches/detail/who-director-general-sstatement-on-ihr-emergency-committee-on-novel-coronavirus-(2019-ncov).

3. EPHI_PHEOC_COVID-19_Weekly_Bulletin_47_English_03252021.pdf.

4. Parpia AS, Ndeffo-Mbah ML, Wenzel NS, Galvani AP. Effects of response to 2014-2015 Ebola outbreak on deaths from malaria, HIV/AIDS, and tuberculosis, West Africa. Volume 22, Number 3March 2016 - Emerg Infect Dis, 2016;22(3):433-441. doi:10.3201/ eid2203.150977

5. Brolin Ribacke KJ, Saulnier DD, Eriksson A, von Schreeb J. Effects of the West Africa Ebola virus disease on health-care utilization - a systematic review. Front Public Health. 2016;4:222. doi: 
10.3389/fpubh.2016.00222.

6. Elston JWT, Cartwright C, Ndumbi P, Wright J. The health impact of the 2014-15 Ebola outbreak. Public Health. 2017;143:6.

7. WHO .Maintaining essential health services: operational guidance for the COVID-19 context .Interim guidance ; June 2020.

8. Strategies and plans: strategic preparedness and response plan [website]. Geneva: World Health Organization; 2020 (https://www.who.int/emergencies/diseases/novel-coronavirus-2019/strategiesand-plans, accessed 8 December 2020).

9. Ribacke KJB, DD Saulnier, A Eriksson, J von Schreeb: Effects of the West Africa Ebola virus disease on health-care utilization - A systematic review. Frontiers in Public Health4;2016: 1-12.

10. Wilhelm JA, and S Helleringer. Utilization of non-Ebola health care services during Ebola outbreaks: A systematic review and meta-analysis. Journal of Global Health 9(1); 2019

11. Sochas L, AA Channon, and S Nam: Counting indirect crisis-related deaths in the context of a lowresilience health system: The case of maternal and neonatal health during the Ebola epidemic in Sierra Leone. Health Policy and Planning 32: 2017: 32-9.

12. Essential Health Services Package of Ethiopia.:Federal Ministry of Health, 2019. Available at: https://www.hfgproject.org/essential-package-of-health-services-country- Snapshotethiopia/.Accessed October 26, 2020

13. Morelli N, Rota E, Terracciano C, Immovilli P, Spallazzi M, Colombi D, et al. Thebaffling case of ischemic stroke disappearance from the casualty department inthe COVID-19 Era. Eur Neurol 2020:1-3, http://dx.doi.org/10.1159/000507666

14. Kansagra AP, Goyal MS, Hamilton S, Albers GW. Collateral effect of Covid-19 onstroke evaluation in the United States. N Engl J Med ;2020, http://dx.doi.org/10.1056/NEJMc2014816.

15. Global financing faculty: Preserve Essential Health Services during the Covid-19 Pandemic, Ethiopia; 2020.

16. Hu"bner M, Zingg T, Martin D, Eckert P,Demartines N Surgery for non-Covid-19 patients during the pandemic. PLoS ONE 15(10) (2020): e0241331. https://doi.org/10.1371/journal.pone.0241331

17. Annual Report of Liaison Office. St. Paul's Hospital Millennium Medical College, Addis Ababa, Ethiopia; 2019.

18. Thérèse McDonnell , Emma Nicholson,et.al Assessing the Impact of COVID-19 Public Health Stages on Paediatric Emergency Attendance: Int. J. Environ. Res. Public Health 2020, 17, 6719; https//doi:10.3390/ijerph17186719

19. The Impact Of Covid-19 On Women (POLICY BRIEF): Population Foundation of India (PFI);2020.

\section{Figures}




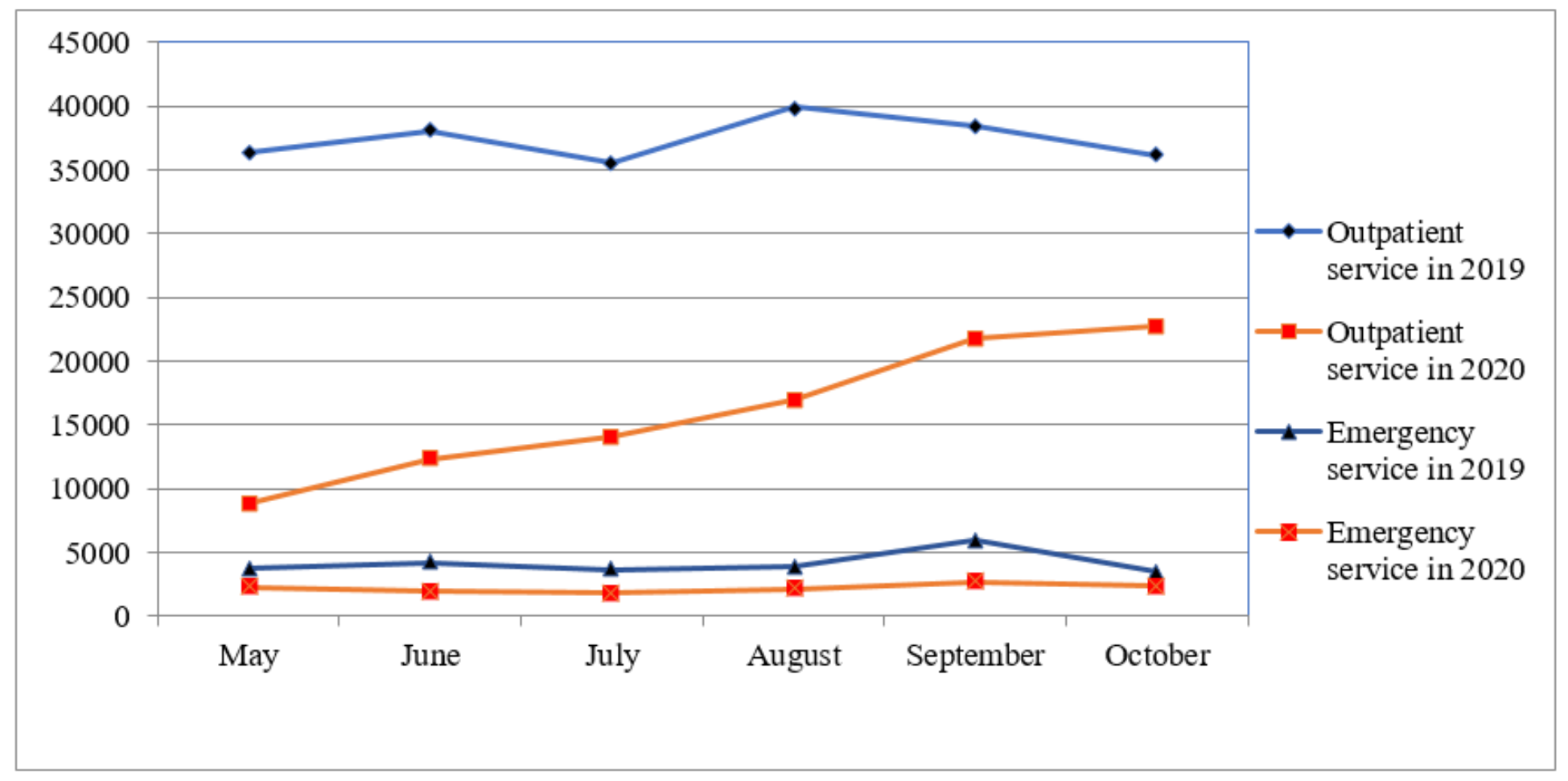

\section{Figure 1}

The number of client who has visited outpatient and emergency department of SPHMMC in 2019(preCOVID 19 season) and 2020(COVID 19 season)

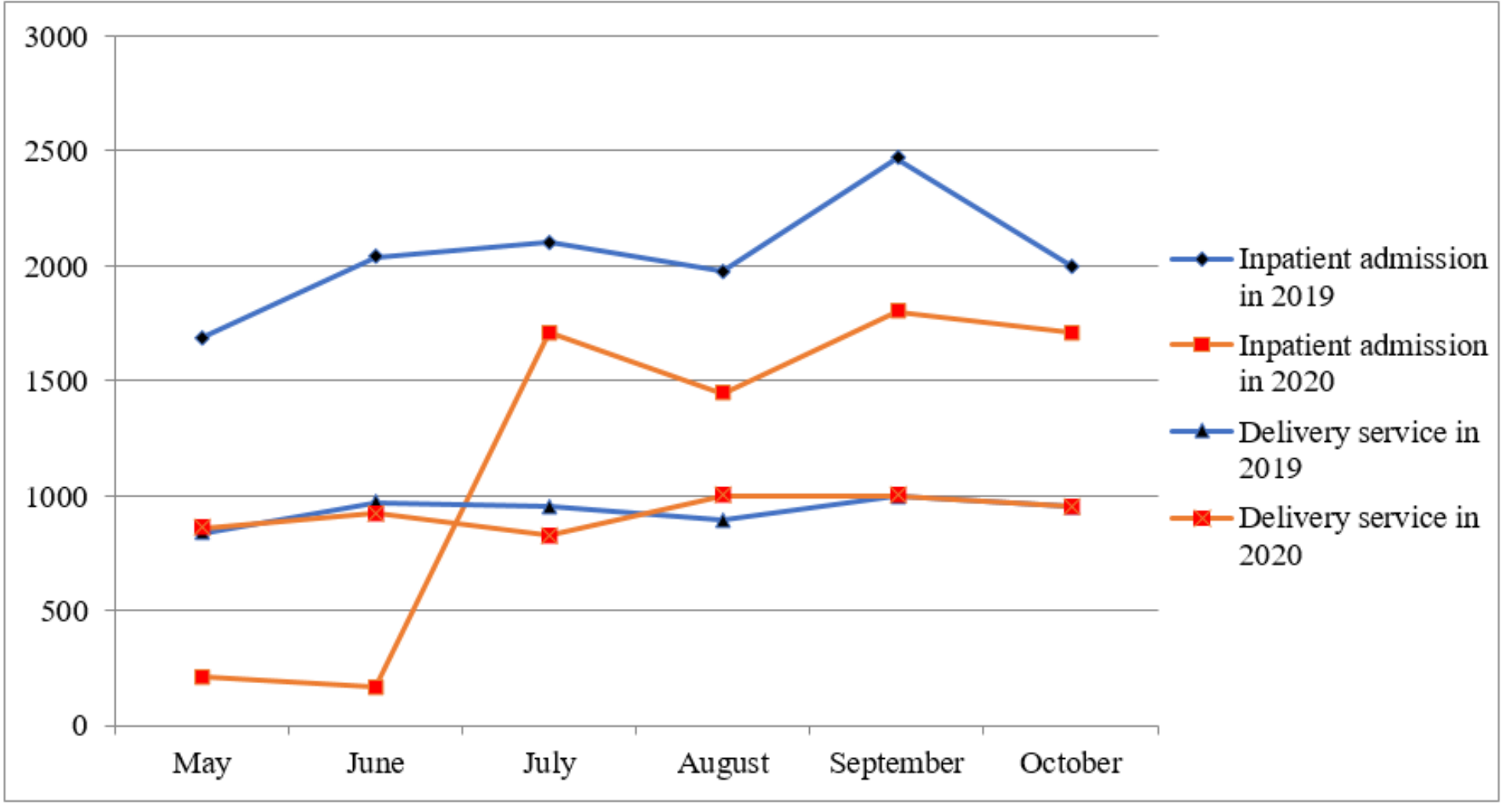

Figure 2 
The number of client admitted to inpatient wards and number of deliveries at SPHMMC in 2019(preCOVID 19 season) and 2020(COVID 19 season)

\section{Supplementary Files}

This is a list of supplementary files associated with this preprint. Click to download.

- QuestionnaireandconsentforlmpactofCOVID19.docx 